\title{
Progress of co-infections of Trichodina cooperi and T. murmanica parasitising farmed Atlantic cod Gadus morhua juveniles in Iceland
}

\author{
Á. Kristmundsson*, M. Eydal, S. Helgason \\ Institute for Experimental Pathology, University of Iceland, Keldur v/Vesturlandsveg, 112 Reykjavík, Iceland
}

\begin{abstract}
Two year classes of wild cod juveniles, caught for on-rearing in shore-based tanks, were examined for Trichodina spp. infections at regular intervals for 9 mo. The prevalence, density and proportion of each species found was determined. Additionally, biomass, seawater temperature and salinity in the tanks was recorded regularly. Two species were identified: T. cooperi and T. murmanica. Their prevalence, density and proportion varied between sampling times, $T$. cooperi being the dominant species, more prevalent and in higher density in the beginning. In the following months, $T$. murmanica gradually increased its prevalence, density and proportion, reaching an almost total dominance in both year classes after 7 mo of rearing. The results indicate that the rearing environment on this farm favoured T. murmanica. Changes in salinity could explain this to some extent; a drop in salinity, due to an inflow of geothermal freshwater to control the temperature during the coldest months, coincided fairly well with an increasing proportion of $T$. murmanica. Transfer of wild fish into the rearing environment, with a subsequent increase in biomass, resulted in a proliferation of trichodinids. This may have altered the interaction between species and the competition for resources. It is conceivable that a higher host density favours one Trichodina species over the other. Temperature could also play a role. During the first 3 to 4 mo of rearing, the temperature in the tanks followed the temperature of the open sea, which dropped by 3 to $5^{\circ} \mathrm{C}$. This study is a part of a larger project on monitoring the progress of various infectious diseases in farmed cod of wild origin.
\end{abstract}

KEY WORDS: Atlantic cod $\cdot$ Trichodina cooperi $\cdot$ Trichodina murmanica $\cdot$ Morphology $\cdot$ Co-infection

Resale or republication not permitted without written consent of the publisher

\section{INTRODUCTION}

In Iceland, the rearing of Atlantic cod Gadus morhua has been in progress for several years. During the developmental phase of hatchery-raised cod juveniles, a simultaneous rearing of juveniles caught in the wild is being developed.

Ectoparasitic trichodinids commonly cause problems in farmed fish. Six species have been reported from Atlantic cod: Trichodina cottidarum (Dogiel 1948, cited by Hemmingsen \& MacKenzie 1993), T. murmanica, T. cooperi, Trichodina sp. (Poynton \& Lom 1989), $T$. domerguei ssp. saintjohnsi (Karasev et al. 1996) and T. claviformis (Dobberstein \& Palm 2000).

The aim of the present study was to examine which Trichodina species occur on cod collected in the wild and reared in shore-based tanks, to follow the progress of these infections and to estimate the proportion of each species, as well as their density and prevalence.

\section{MATERIALS AND METHODS}

In September 2002 and 2003, wild cod juveniles in their first year (approx. $5 \mathrm{~cm}$ long) were caught in the coastal waters of Isafjordur, West Iceland. The fish were brought to a nearby shore-based facility and reared in tanks for 9 mo. Subsequently, at the approximate length of 20 to $30 \mathrm{~cm}$, they were transported to sea cages for further rearing. During the shore-based period a group of fish from each of these 2 year classes (y.cl.) was kept untreated for ectoparasites and exam- 
Table 1. Time of sampling and number of fish examined at each sampling time

\begin{tabular}{|ccccccc|}
\hline Year class 2002 & Sampling time & - & 10 Dec 2002 & 17 Feb 2003 & 1 Apr 2003 & 9 Jun 2003 \\
& $n$ & 0 & 30 & 30 & 20 \\
Year class 2003 & Sampling time & 23 Sep 2003 & 21 Nov 2003 & 27 Jan 2004 & 1 Apr 2004 & 9 Jun 2004 \\
& $n$ & 30 & 40 & 30 & 20 & 20 \\
\hline
\end{tabular}

ined regularly for Trichodina spp. infections. The time of observations and number of fish examined on each occasion are shown in Table 1.

Skin scrapings were taken from an approximately $1.5 \mathrm{~cm}^{2}$ area posterior to the pectoral fin and examined microscopically. The observed Trichodina species were identified and counted, and the prevalence and density of infections were determined for each species. The density on each fish was determined as: no infection $=0$, mild $(1$ to 10 individuals per sample $[\mathrm{i} / \mathrm{s}])=1$, medium (11 to $50 \mathrm{i} / \mathrm{s})=2$ and heavy infection (>50 i/s) $=3$. From these data the mean infection density for all the fish examined was calculated. The proportion/ dominance of species on every examined fish was determined, as well as the mean proportion on all examined fish at each sampling time. In addition, gills and fins were examined microscopically for the presence of trichodinids. Biomass, salinity and seawater temperature in the tanks was recorded regularly through the examination period. The seawater was pumped into the tanks from a depth of $30 \mathrm{~m}$ in the open sea. The seawater temperature in the tanks was controlled by an inflow of geothermal freshwater, which resulted in some salinity fluctuations. Heating of the seawater started in mid-January and the beginning of December for y.cl. 2002 and 2003, respectively.

For species identification, a modification of Klein's dry method (Klein 1958), as described by Lom (1958) was employed, to demonstrate the components of the adhesive disc, as well as the structure of the spiral of the adoral ciliature. Air-dried samples were washed with distilled water prior to staining with $2 \% \mathrm{AgNO}_{3}$, to minimise the precipitation of chlorides with $\mathrm{AgNO}_{3}$. Samples were stained for $8 \mathrm{~min}$, then washed with distilled water and finally exposed to UV-light for $25 \mathrm{~min}$, dried and mounted in mountex. The Feulgen reaction (Carson 1990) was used to reveal the structure of the nuclear apparatus.

Definitions of ecological terms are according to Bush et al. (1997). Terminology and methods of measure- ments are those given by Lom (1958) and Van As \& Basson (1989). All dimensions were measured (in $\mu \mathrm{m}$ ), and photographs were taken using a Leica DMLB microscope equipped with a digital camera (Leica DC300F).

\section{RESULTS}

\section{Descriptions of species}

Morphometric data of Trichodina cooperi Poynton \& Lom 1989 infecting Gadus morhua from Icelandic and, for comparison, Canadian waters (Poynton \& Lom 1989) are summarised in Table 2.

This species is characterised by its large size, dome shape in lateral view (with height less than width) and a distinct dark centre (Fig. 1). The body diameter of our specimens measured 95 to $115 \mu \mathrm{m}$, the diameter of the adhesive disc was 80 to $104 \mu \mathrm{m}$ and the diameter of the denticle ring was 53 to $67 \mu \mathrm{m}$. The number of denticles ranged from 25 to 29 , and the number of radial pins per denticle was 8 to 15 . Body membrane width was 5.5 to $8.0 \mu \mathrm{m}$. The blades were relatively broad, and the anterior and posterior margins were nearly parallel.
Table 2. Trichodina cooperi. Morphometric data of ectoparasite infecting Atlantic cod Gadus morhua (skins and fins) from Icelandic and Canadian (Nova Scotia) waters (Poynton \& Lom 1989)

\begin{tabular}{|lcccr|}
\hline & Present study & & Poynton \& Lom (1989) \\
& Mean (range) & $\mathrm{n}$ & Mean (range) & $\mathrm{n}$ \\
& & & & \\
\hline Body diameter $(\mu \mathrm{m})$ & $108.8(95-115)$ & 15 & $110(95-122)$ & 14 \\
Diameter of adhesive disc $(\mu \mathrm{m})$ & $95.7(80-104)$ & 15 & $95(82-107)$ & 17 \\
Diameter of denticle ring $(\mu \mathrm{m})$ & $61.6(53-67)$ & 15 & $59(49-67)$ & 21 \\
No. of denticles & $27(25-29)$ & 15 & $27(24-29)$ & 21 \\
Width of body membrane $(\mu \mathrm{m})$ & $6.9(5.5-8.0)$ & 15 & $7.4(6.4-8.9)$ & 14 \\
No. of radial pins per denticle & $8-15$ & 15 & $7-9$ & 21 \\
Span of denticle $(\mu \mathrm{m})$ & $25.7(24.0-30.0)$ & 13 & $28.5(23.6-32.5)$ & 17 \\
Length of denticle $(\mu \mathrm{m})$ & $23.5(21.0-25.0)$ & 13 & $21.5(20.4-24.5)$ & 8 \\
Length of blade $(\mu \mathrm{m})$ & $9.0(8.0-10.0)$ & 13 & $8.6(7.5-10.0)$ & 12 \\
Width of central part $(\mu \mathrm{m})$ & $4.5(4.0-5.0)$ & 13 & $4.8(3.2-6.3)$ & 13 \\
Length of thorn $(\mu \mathrm{m})$ & $13.2(10.0-15.5)$ & 13 & $15.4(10.2-19.1)$ & 15 \\
Diameter of macronucleus $(\mu \mathrm{m})$ & $65.4(54.0-75.0)$ & 14 & $80.6(69.9-95)$ & 15 \\
Thickness of macronucleus $(\mu \mathrm{m})$ & $7.2(5.5-9.0)$ & 14 & $12.4(9.2-17.0)$ & 14 \\
Distance between arms of & & & & \\
$\quad$ macronucleus $(\mu \mathrm{m})$ & $17.6(14.0-25.0)$ & 14 & $18(12.8-24.1)$ & 14 \\
Adoral zone (in degrees) & $(380-390)$ & 14 & $380(370-390)$ & - \\
\hline
\end{tabular}



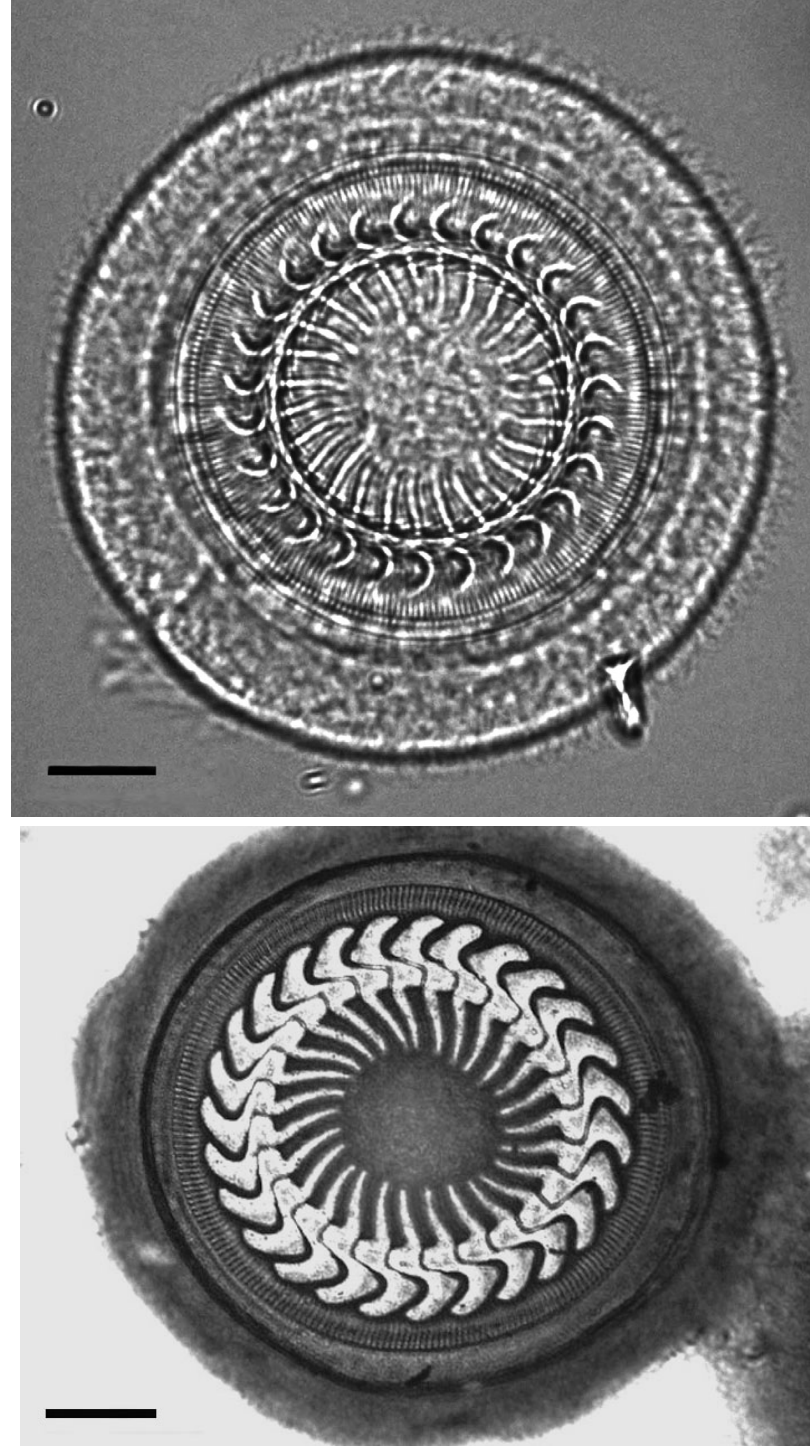

Fig. 1. Trichodina cooperi. Live (upper panel) and silverimpregnated (lower panel) specimens from juvenile Atlantic cod Gadus morhua. Bars: $20 \mu \mathrm{m}$

The tangent point was below the curved distal surface. A blade apex was present, extending prominently beyond the Y+1 axis. Blade apophysis was absent. The anterior margin of the blade formed an approximately $45^{\circ}$ angle with the $\mathrm{Y}+1$ axis. The posterior margin formed a relatively deep curve and was not in good correspondence with the blade apex. The central part was a square form, extending more than half-way towards the Y-1 axis and fitting loosely into the preceding denticle. Sections above and below the $\mathrm{X}$-axis were similar in shape. Rays were rather long, moderately broad, slightly curved and projecting posteriorly. Ray apophysis was absent (Fig. 2). The dimensions of the denticles are given in Table 2 . The macronucleus was horseshoe-shaped (Fig. 3); the dimensions of the macronucleus are also presented in Table 2. A micronucleus was not detected. The adoral ciliature formed a spiral of approximately 380 to $390^{\circ}$ (Fig. 4).

Morphometric data of Trichodina murmanica Polyanskiy, 1955 isolated in this study and a comparison of these with specimens isolated elsewhere is summarised in Table 3.

This medium-sized Trichodina species is characterised by its clear centre containing darkly stained granules in silver-impregnated specimens (Fig. 5). In lateral view it is dome shaped. The body diameter of our specimens was 48 to $59 \mu \mathrm{m}$, the diameter of the adhesive disc was 42 to $52 \mu \mathrm{m}$, and the diameter of the denticle ring was 26 to $33 \mu \mathrm{m}$. The number of denticles ranged from 25 to 28 , and the number of radial pins per denticle was 6 to 10. The blades are sickle shaped, filling most of the area between the Y-axes. The anterior margin was curved, barely distinguishable from the distal surface. The tangent point was blunt and somewhat below the distal surface. Blade apophysis was absent. The anterior margin of the blade formed an approximately $40^{\circ}$ angle with the $\mathrm{Y}+1$ axis. The blade apex was present; it was rounded and extended slightly beyond the $\mathrm{Y}+1$ axis. The posterior margin was slightly curved, the deepest point corresponding to the blade apex. The central part was triangular, extending $>3 / 4$ of the way towards the $\mathrm{Y}-1$ axis and fitting tightly into the preceding denticle. Sections above and below the Xaxis were similar in shape. Rays were short, broad and

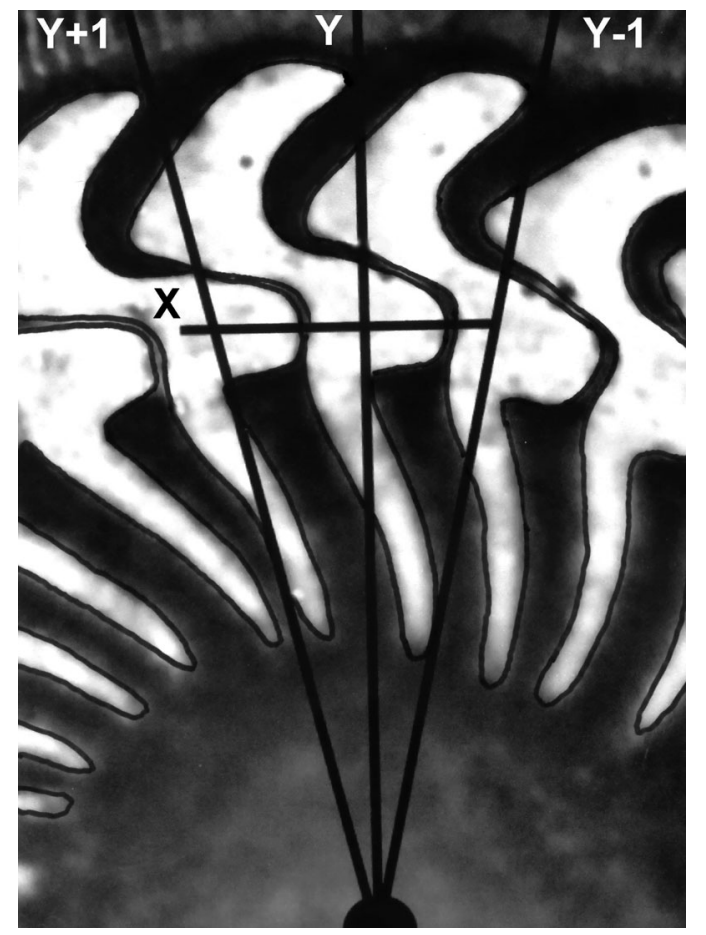

Fig. 2. Trichodina cooperi. Shape of denticles 


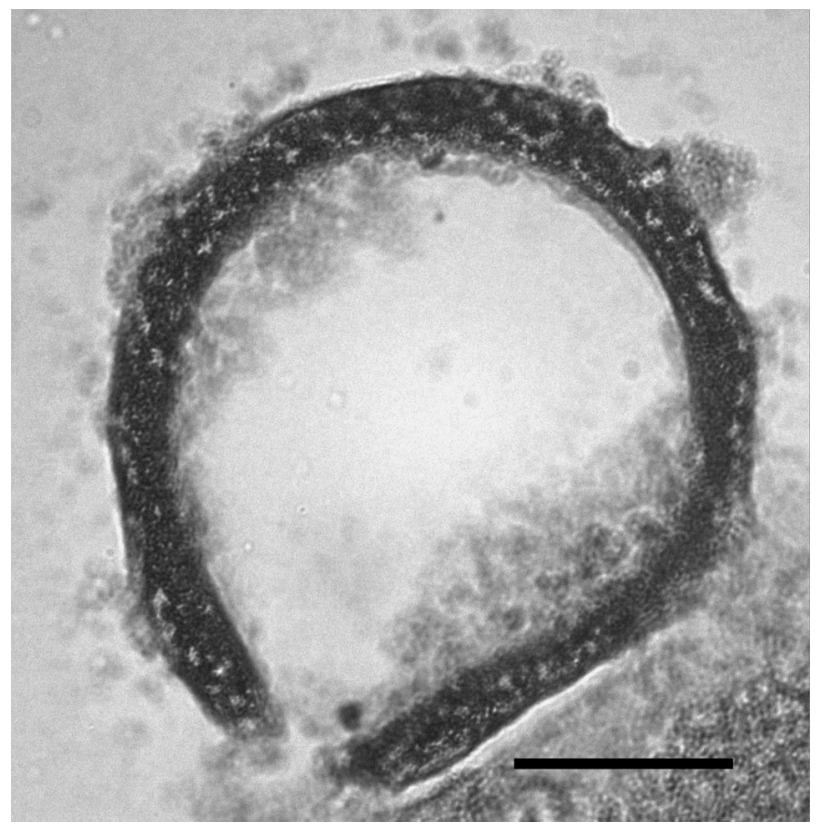

Fig. 3. Trichodina cooperi. Macronucleus (Feulgen reaction). Bar: $20 \mu \mathrm{m}$

slightly curved, projecting to the geometrical centre or somewhat anteriorly (Fig. 6). The dimensions of the denticles are given in Table 3. The macronucleus was horseshoe-shaped (Fig. 7); its morphometric data are also given in Table 3. A micronucleus was not detected. The adoral ciliature formed a spiral of approximately 380 to $390^{\circ}$ (Fig. 8).

\section{Sites of infection}

Both species equally infected gills, fins and skin. There was a positive correlation between the density on gills, skin and fins for both species.

\section{Prevalence and density}

The prevalence and density of Trichodina species at different sampling times is shown in Figs. 9 \& 10, respectively.

At the start of the rearing period (September, no data for y.cl. 2002), only Trichodina cooperi was detected in low prevalence $(13.3 \%)$. In November to December, the prevalence of Trichodina spp. had reached $100 \%$ in both year classes. In y.cl. 2002, this was $100 \%$ for T. cooperi and $97.5 \%$ for y.cl. 2003 ; for T. mur-

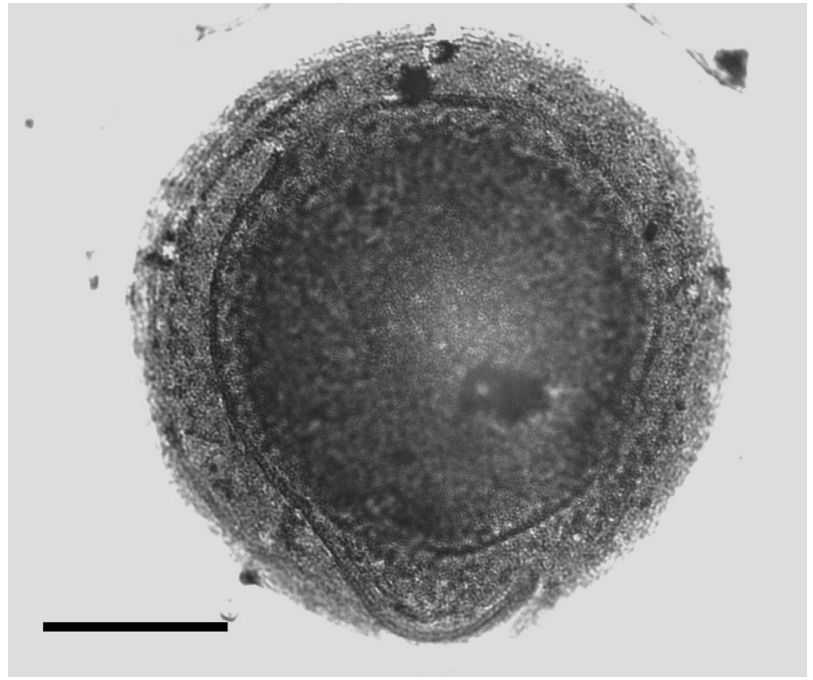

Fig. 4. Trichodina cooperi. Adoral ciliature forming a spiral of 380 to $390^{\circ}$ (silver-impregnated specimen). Bar: $20 \mu \mathrm{m}$

manica, this was about $3 \%$ in y.cl. 2002 and $80 \%$ in y.cl. 2003. In January to February, the prevalence of both species was high (87 to $100 \%$ ), though that of $T$. murmanica was slightly higher in y.cl. 2003. In April, $T$. cooperi was not detected in y.cl. 2002, and the prevalence in y.cl. 2003 had dropped to $15 \%$. For T. murmanica, the figures were 63 and $95 \%$, respectively, in y.cl. 2002 and 2003. In June, the prevalence of $T$. cooperi rose again in y.cl. $2002(77 \%)$, but remained the same in y.cl. $2003(15 \%)$. The prevalence of $T$. murmanica remained high (90 to $100 \%$ ).

Table 3. Trichodina murmanica. Morphometric data of ectoparasite infecting Atlantic cod Gadus morhua (skin and fins) from Icelandic and Canadian (Nova Scotia) waters (Poynton \& Lom 1989)

\begin{tabular}{|c|c|c|c|c|}
\hline & \multirow{2}{*}{$\begin{array}{l}\text { Present study } \\
\text { Mean (range) }\end{array}$} & \multicolumn{3}{|c|}{ Poynton \& Lom (1989) } \\
\hline & & $\mathrm{n}$ & Mean (range) & $\mathrm{n}$ \\
\hline Body diameter $(\mu \mathrm{m})$ & $53.0(48-59)$ & 20 & $62(51-72)$ & \\
\hline Diameter of adhesive disc $(\mu \mathrm{m})$ & $46.9(42-52)$ & 20 & $51(43-61)$ & \\
\hline Diameter of denticle ring $(\mu \mathrm{m})$ & $28.5(26-33)$ & 20 & $34(26-42)$ & to y \\
\hline No. of denticles & $28(25-30)$ & 20 & $28(25-31)$ & $\stackrel{2}{*}$ \\
\hline Width of body membrane $(\mu \mathrm{m})$ & $3.4(2-4.5)$ & 20 & $4.5(3.0-5.2)$ & 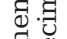 \\
\hline No. of radial pins per denticle & $6-10$ & 20 & $7-10$ & हี ฮ \\
\hline Span of denticle $(\mu \mathrm{m})$ & $12.0(10.5-14.0)$ & 20 & $13.5(8.0-15.2)$ & $\bar{m}$ \\
\hline Length of denticle $(\mu \mathrm{m})$ & - & & - & चृ \\
\hline Length of blade $(\mu \mathrm{m})$ & $5.2(4.0-7.0)$ & 20 & $5.3(4.4-6.0)$ & $\sum \stackrel{1}{N}$ \\
\hline Width of central part $(\mu \mathrm{m})$ & $2.3(2.0-3.5)$ & 20 & $2.1(1.4-3.2)$ & \\
\hline Length of thorn $(\mu \mathrm{m})$ & $4.9(3.5-6.5)$ & 20 & $6.1(4.8-7.0)$ & \\
\hline Diameter of macronucleus $(\mu \mathrm{m})$ & $39.4(31.0-47.5)$ & 10 & $41(34-58)$ & 9 \\
\hline Thickness of macronucleus ( $\mu \mathrm{m})$ & $7.4(6.0-8.8)$ & 10 & - & - \\
\hline $\begin{array}{l}\text { Distance between arms of } \\
\text { macronucleus }(\mu \mathrm{m})\end{array}$ & $14.5(10-25)$ & 10 & - & - \\
\hline Adoral zone (in degrees) & $(380-390)$ & 12 & $380(370-380)$ & - \\
\hline
\end{tabular}



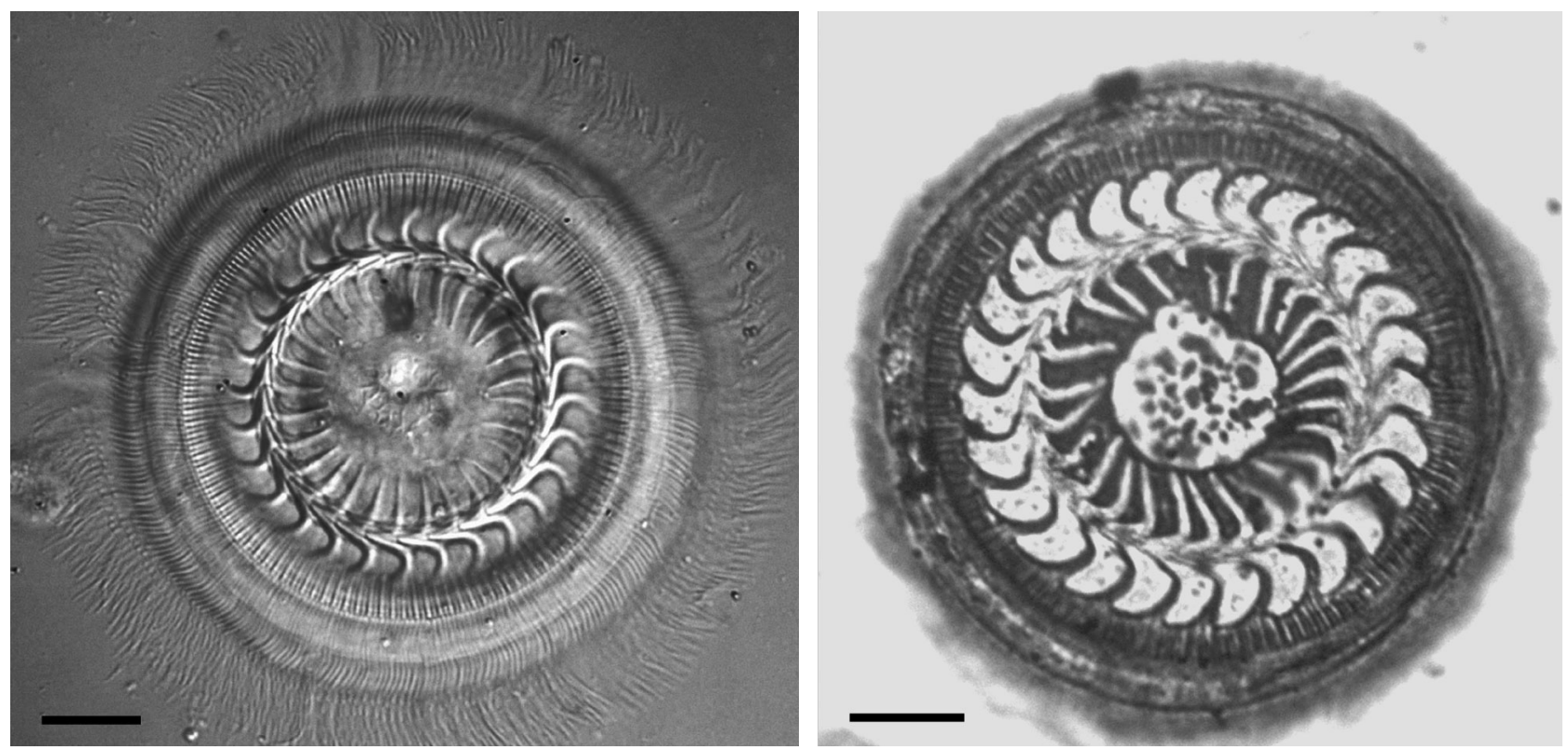

Fig. 5. Trichodina murmanica. Live (left panel) and silver-impregnated (right panel) specimens from juvenile Atlantic cod Gadus morhua. Bar: $10 \mu \mathrm{m}$

In September the mean density of Trichodina cooperi was low (no data for y.cl. 2002). In January to February, the density of the 2 species was similar, but slightly higher for T. murmanica. For the latter species, the density had increased greatly since the November to December observation, but had dropped slightly for $T$. cooperi. In April, only $15 \%$ of fish of y.cl. 2003 had mild infections of $T$. cooperi. T. murmanica infections were generally mild in y.cl. 2002, but heavy in y.cl. 2003 (Fig. 10). In June, the density of $T$. cooperi was, in most cases, low. For T. murmanica, it rose in y.cl. 2002,

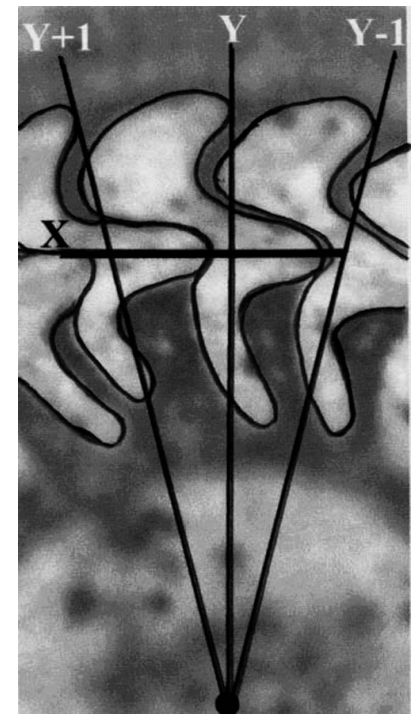

Fig. 6. Trichodina murmanica. Shape of denticles but dropped in y.cl. 2003, though it was much higher than for T. cooperi.

\section{Proportion/dominance of species}

The mean proportion of each species in the total infection varied between sampling dates (Fig. 11). Trichodina cooperi was the dominant species the first months of the rearing period. At the beginning of this period, it was completely dominant (no observation made on y.cl. 2002), which gradually changed

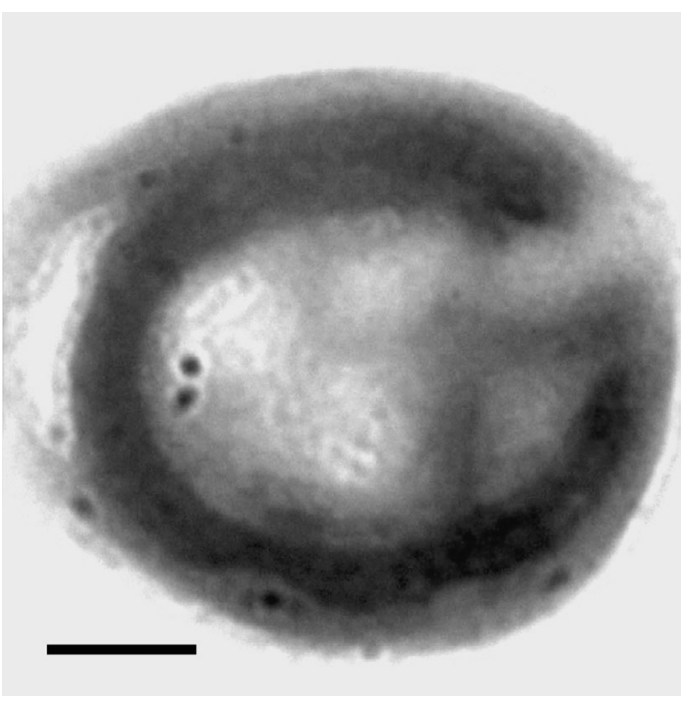

Fig. 7. Trichodina murmanica. Macronucleus (Feulgen reaction). Bar: $10 \mu \mathrm{m}$ 


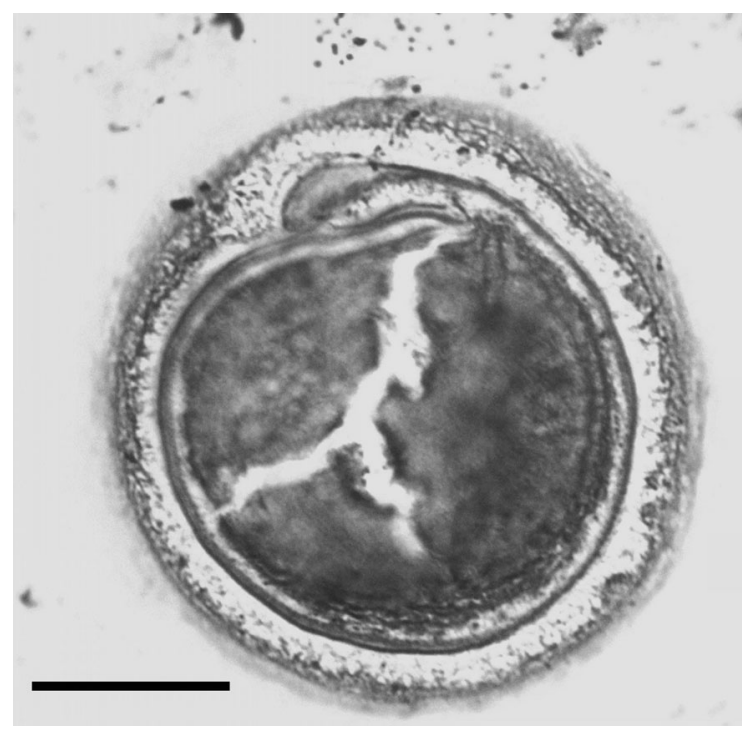

Fig. 8. Trichodina murmanica. Adoral ciliature forming a spiral of 380 to $390^{\circ}$ (silver-impregnated specimen). Bar: $10 \mu \mathrm{m}$

(declined) in the following months and, by January to February, T. murmanica had become the dominant species in both year classes (60 and 63\%). Subsequently, the proportion of T. murmanica continued to rise, and, in April, it was almost completely dominant in both year classes (100 and $98 \%$ ). The 2 last months of the experimental period, the proportion of $T$. cooperi rose again in y.cl. $2002(26.5 \%)$, but remained the same in y.cl. $2003(2 \%)$.

\section{Biomass, salinity and temperature}

Data on biomass, salinity and temperature and the relationships with Trichodina spp. infection prevalence, infection density and T. cooperi proportion of infection are shown in Figs. 12 to 20.

The biomass in the experimental tanks varied during the examination time, ranging from 5 to $13 \mathrm{~kg} \mathrm{~m}^{-3}$ in y.cl. 2002 and from 5 to $9 \mathrm{~kg} \mathrm{~m}^{-3}$ in y.cl. 2003 (Table 4). The observed biomass was affected both by differences in mortality, which were commonly high among the newly caught juveniles at the beginning of the rearing phase, but also by the growth of the individual fish in the tanks. These groups of fish were not size-graded, and no transfer of live fish took place. There is an apparent positive correlation between fluctuations in biomass, and the prevalence and mean density of Tri-

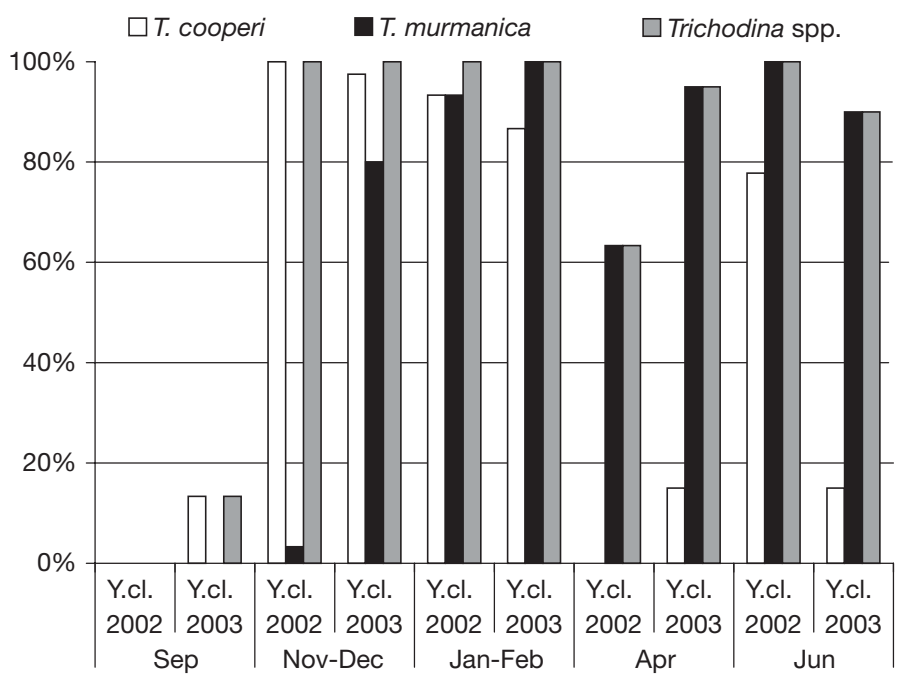

Fig. 9. Gadus morhua. Prevalence of Trichodina spp. infections in both year classes at each sampling time

chodina spp. infections, and also the proportion of $T$. cooperi in y.cl. 2002. No such correlation was evident in y.cl. 2003 (Figs. 12 to 14).

Salinity ranged from 30 to $35 \%$ throughout the rearing period. The salinity was maximum at the beginning and end of the experiment, but reached its minimum in March to April. In general, the proportion of Trichodina cooperi decreased along with reduced salinity and reached its minimum (0 to $2 \%$ ) in April, when the salinity was just beginning to rise again. The proportion of $T$. cooperi rose a little in y.cl. 2002, when salinity increased again, but for y.cl. 2003

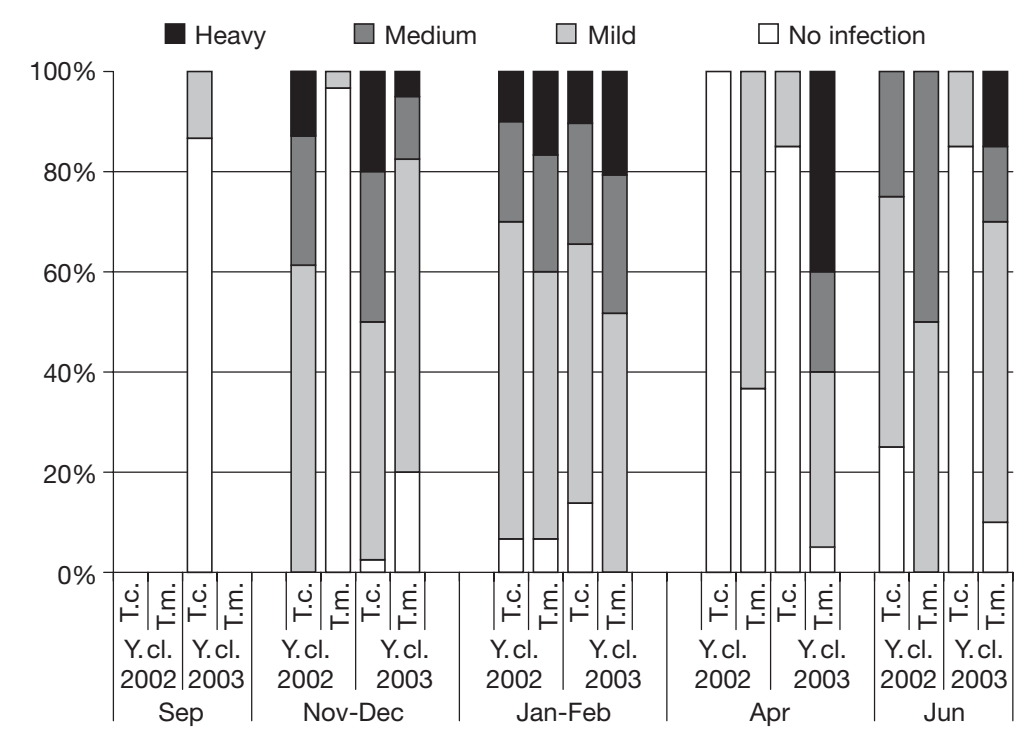

Fig. 10. Trichodina cooperi, T. murmanica. Infection density in both year classes of juvenile Atlantic cod Gadus morhua at each sampling time 


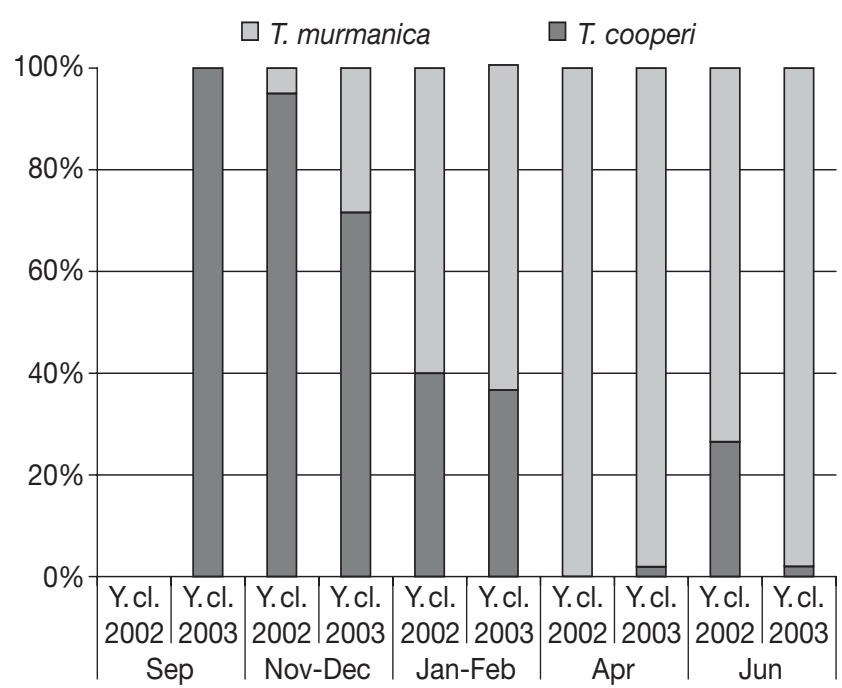

Fig. 11. Trichodina cooperi, T. murmanica. Proportion of each species in total infections of both year classes of juvenile Atlantic cod Gadus morhua it remained the same despite increasing salinity (Fig. 15). The data show no obvious relationship between salinity, on the one hand, and the prevalence or mean density of Trichodina spp., on the other hand (Figs. $16 \& 17$ ).

During the experiment, the seawater temperature ranged from 6 to $9^{\circ} \mathrm{C}$ (y.cl. 2002) and from 6 to $11^{\circ} \mathrm{C}$ (y.cl. 2003). Neither the proportion of Trichodina cooperi nor the prevalence and density of Trichodina spp. seem to be markedly affected by temperature (Figs. 18 to 20).

\section{DISCUSSION}

This is the first record of Trichodina cooperi and $T$. murmanica from Icelandic fish and thus extends the known geographic distribution of these species.

Trichodina murmanica has low host specificity and has been reported from various and distinct fish spe-

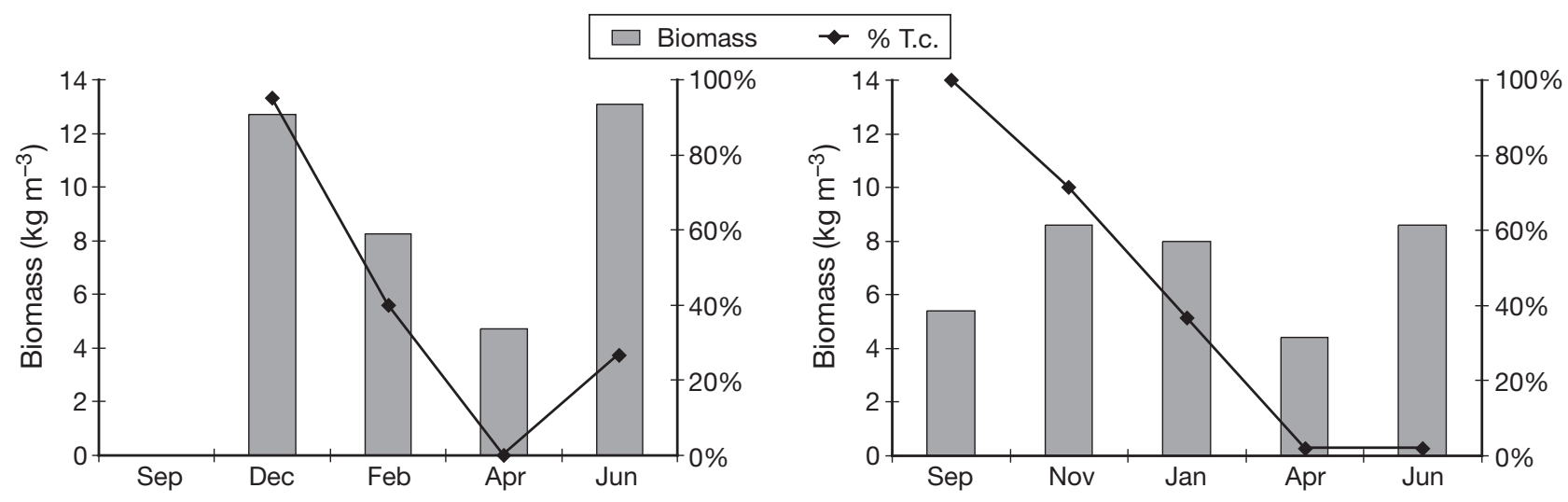

Fig. 12. Trichodina cooperi. Relationship between host (Gadus morhua) biomass $\left(\mathrm{kg} \mathrm{m}^{-3}\right)$ and proportion of total infection in year classes 2002 (left panel) and 2003 (right panel) at different sampling times

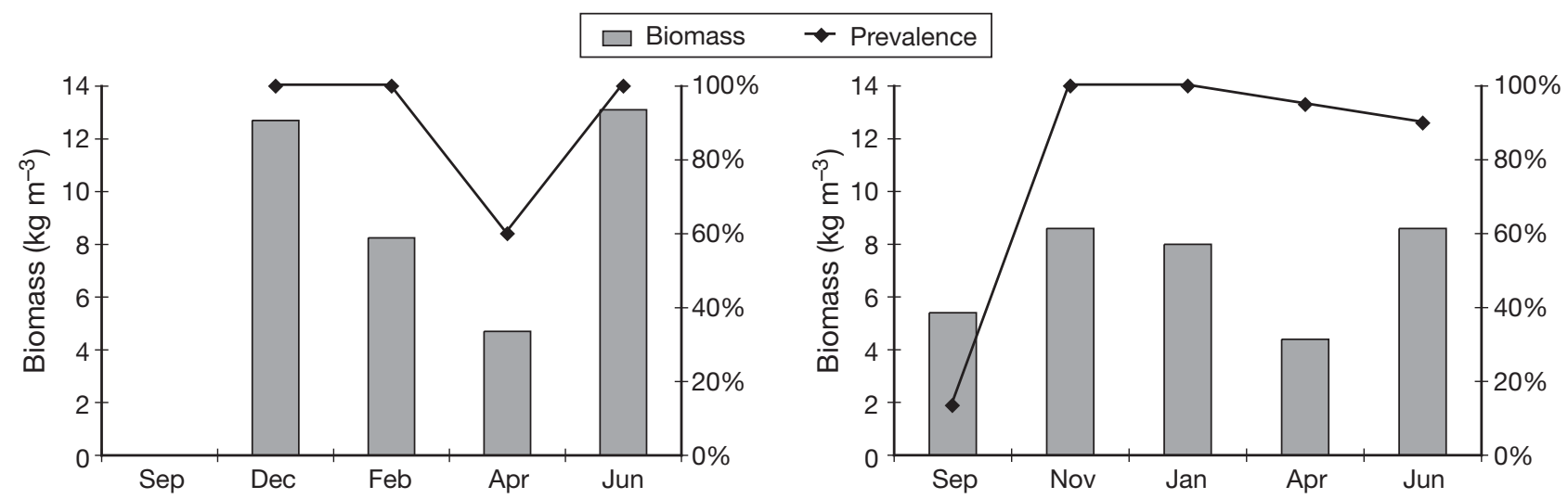

Fig. 13. Trichodina spp. Relationship between host (Gadus morhua) biomass $\left(\mathrm{kg} \mathrm{m}^{-3}\right)$ and prevalence of infection in year classes 2002 (left panel) and 2003 (right panel) at different sampling times 


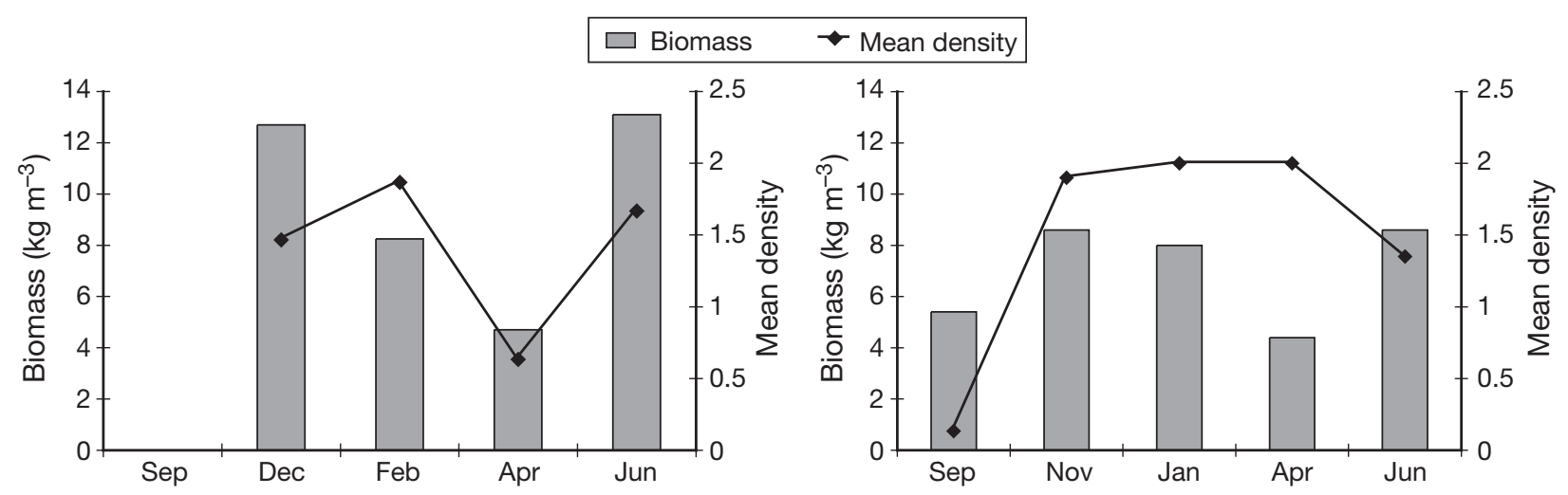

Fig. 14. Trichodina spp. Relationship between host (Gadus morhua) biomass ( $\left.\mathrm{kg} \mathrm{m}^{-3}\right)$ and mean density of infection in year classes 2002 (left panel) and 2003 (right panel) at different sampling times

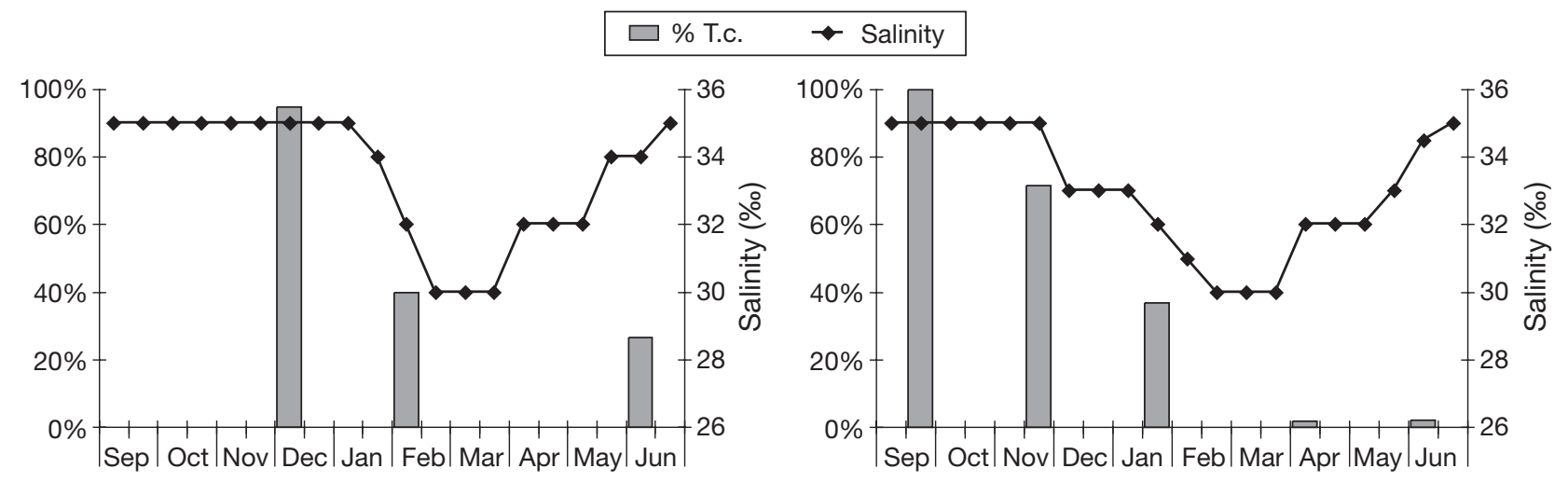

Fig. 15. Trichodina cooperi. Relationship between salinity (\%) and proportion of infection in juvenile Atlantic cod Gadus morhua year classes 2002 (left panel) and 2003 (right panel) at different sampling times

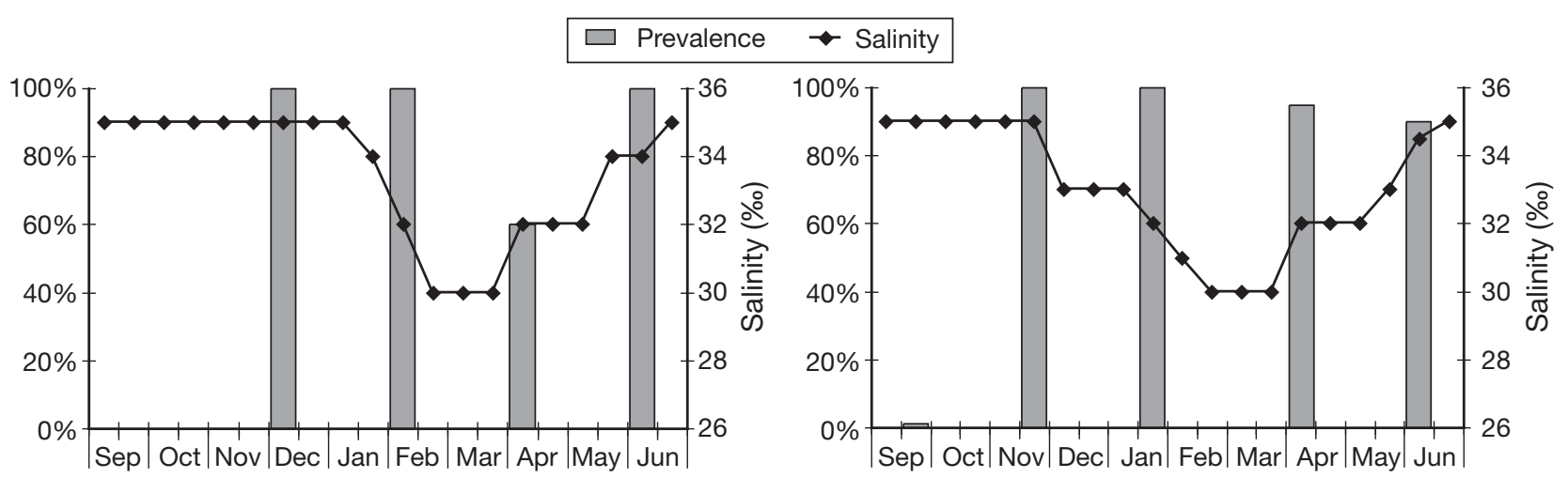

Fig. 16. Trichodina spp. Relationship between salinity (\%) and prevalence of infection in juvenile Atlantic cod Gadus morhua year classes 2002 (left panel) and 2003 (right panel) at different sampling times

cies, wild and cultured, from many different geographic areas. It has been described from wild and cultured cod Gadus morhua in Atlantic Canadian waters (Poynton \& Lom 1989, Khan 2004), the Barents and White Seas (Polyanskiy 1955, Shtein 1976, Karasev et al. 1996) and Chukotka (Siberia) (Zhukov 1964), from saithe Pollachius virens from the Barents and White Seas (Polyanskiy 1955, Karasev et al. 1996) and from various other non-gadoids such as winter flounder Pseudopleuronectes americanus in Canadian waters (Barker et al. 2002), Cyclopterus sp., Triglops murrayi and Myoxocephalus scorpius from Grand Banks in Atlantic Canada (Lom \& Laird 1969), Lumpus sp. and Myoxocephalus scorpius from the 


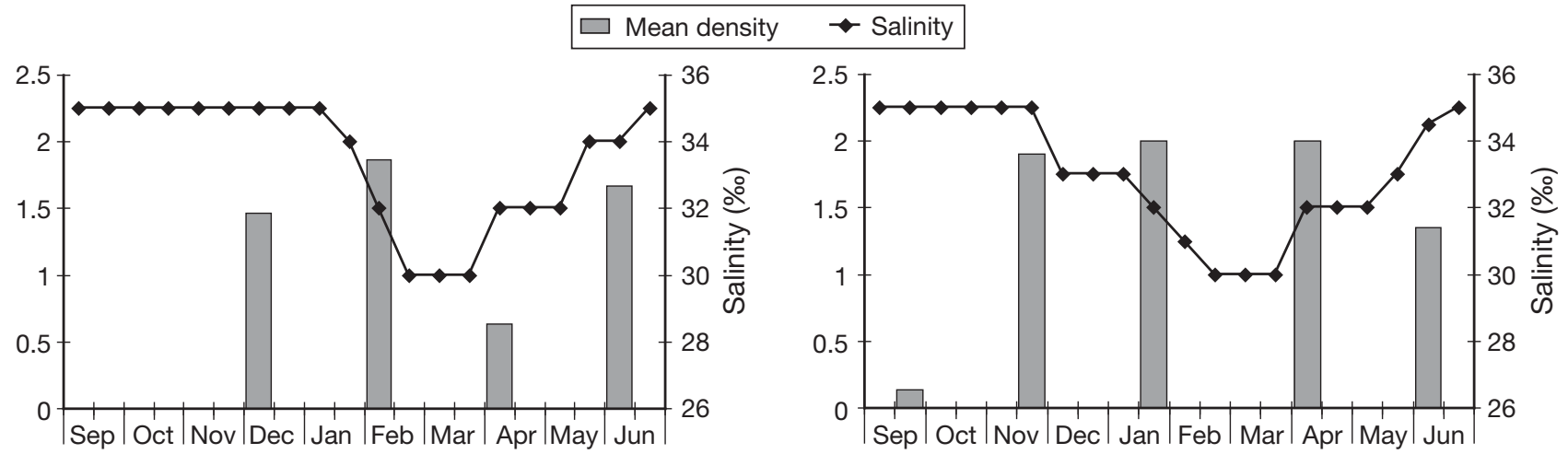

Fig. 17. Trichodina spp. Relationship between salinity (\%) and mean density of infection in juvenile Atlantic cod Gadus morhua year classes 2002 (left panel) and 2003 (right panel) at different sampling times

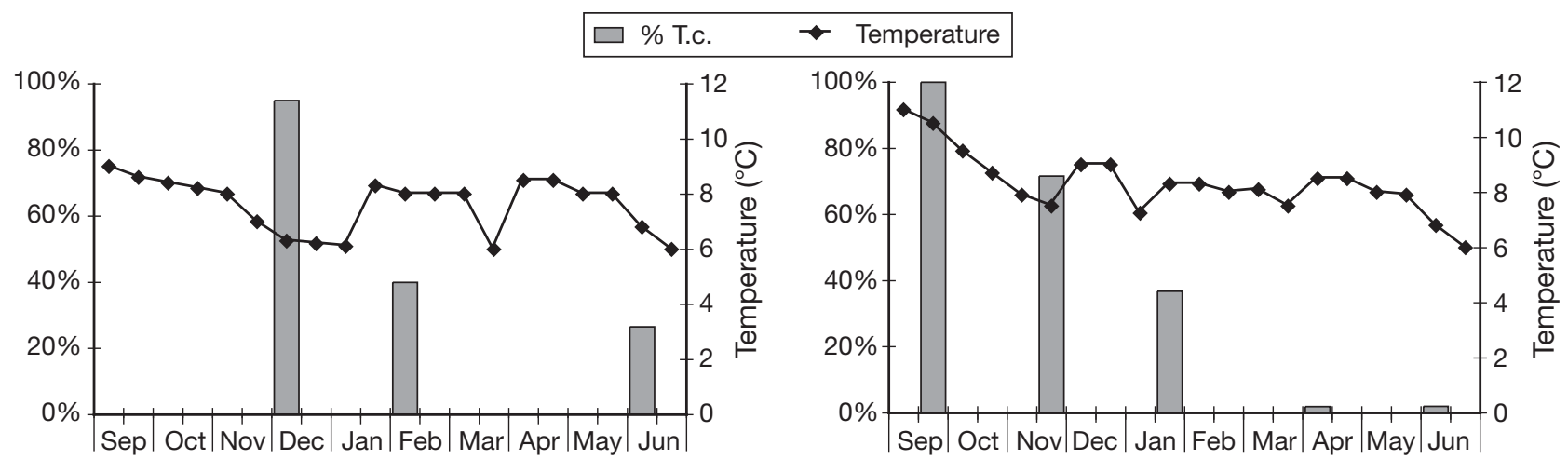

Fig. 18. Trichodina cooperi. Relationship between temperature $\left({ }^{\circ} \mathrm{C}\right)$ and proportion of infection in juvenile Atlantic cod Gadus morhua year classes 2002 (left panel) and 2003 (right panel) at different sampling times

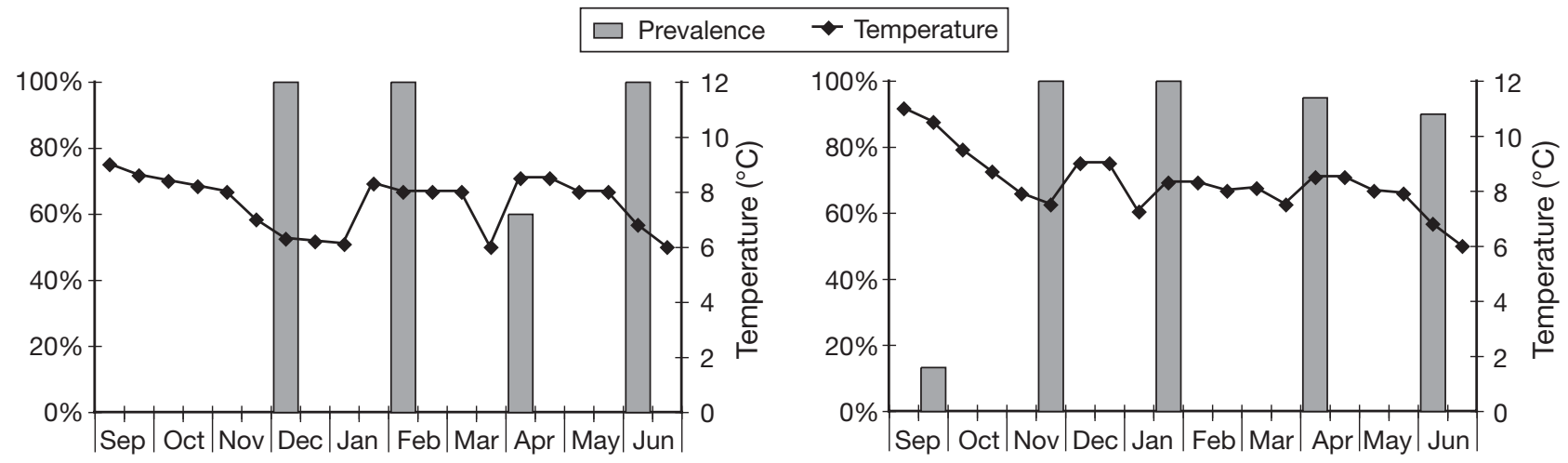

Fig. 19. Trichodina spp. Relationship between temperature $\left({ }^{\circ} \mathrm{C}\right)$ and prevalence of infection in juvenile Atlantic cod Gadus morhua year classes 2002 (left panel) and 2003 (right panel) at different sampling times

White Sea (Shtein 1976), Pholis gunellus and Myoxocephalus scorpius from the Barents Sea (Shtein 1973) and Acanthopagrus macrocephalus from the Yellow Sea in South East China (Xu et al. 1999). Yet, the only known host for T. cooperi is Atlantic cod G. morhua. Since its original description (Poynton \& Lom 1989), it has, to the best of our knowledge, only once been reported (Nilsen 2002). No mortality has been re- ported due to T. cooperi infections, but mass mortalities of farmed Atlantic cod have been associated with T. murmanica infections (Khan 2004). In the present study no attempt was made to evaluate the significance of Trichodina spp. infections on the host, because of co-infections of Ichthyobodo spp.

At the beginning of the rearing period, the prevalence and density of detectable Trichodina spp. infec- 


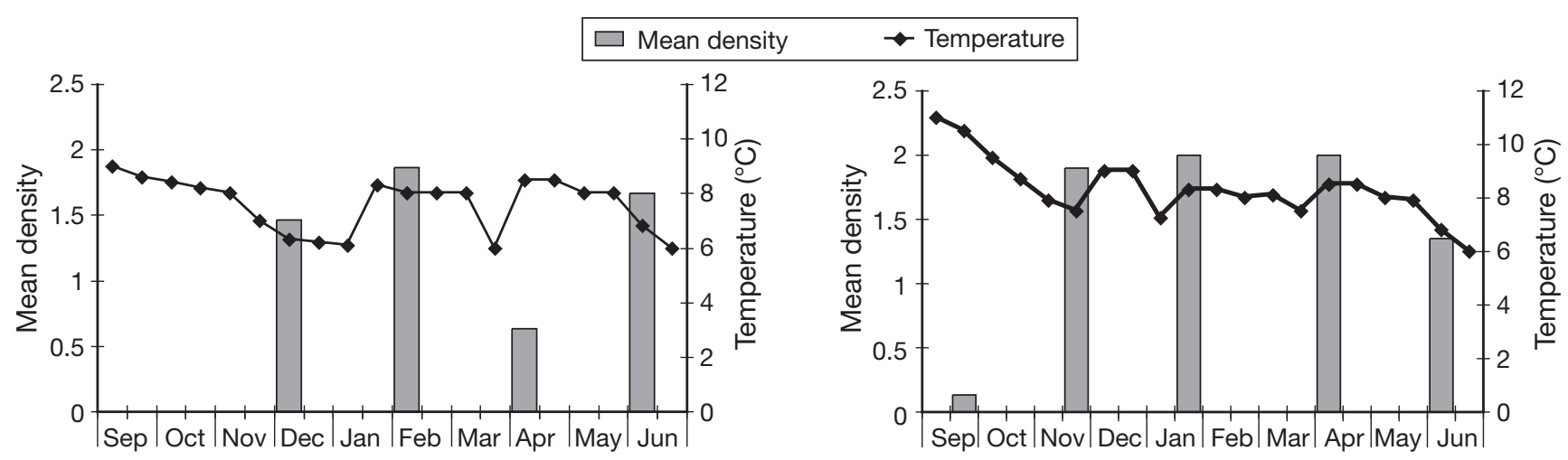

Fig. 20. Trichodina spp. Relationship between temperature $\left({ }^{\circ} \mathrm{C}\right)$ and mean density of infection in juvenile Atlantic cod Gadus morhua year classes 2002 (left panel) and 2003 (right panel) at different sampling times

tions was low. After 3 mo rearing, by November to December, the prevalence had reached $100 \%$ in both year classes and the density was higher. From this point until the end of the rearing period, the prevalence remained high and, generally, so did the density. Some fluctuations occurred, which were most likely related to variations in biomass, rather than in salinity or temperature. This development of prevalence and density is not surprising, considering the following: although Trichodina species are common in wild fish, their density in the wild is seldom high. In the farming environment the biomass per unit volume is much higher than in nature, and, therefore, optimal conditions arise for these infections to increase rapidly. On the other hand, it is interesting that the same progress in the co-infection pattern of Trichodina species occurs in both year classes. At the beginning of the rearing period, only T. cooperi was detected. After 3 mo of rearing, T. murmanica appeared, but its proportion was low: 3 and 26\% in y.cl. 2002 and 2003, respectively. In the following months, T. murmanica gradually increased its proportion and reached almost complete dominance in both year classes by April. Until the end of the rearing period, T. murmanica remained the dominant species, although the last observation showed a slightly increased proportion of $T$. cooperi in y.cl. 2002. What could explain this analogous co-infection pattern in these 2 successive year classes? Are

Table 4. Gadus morhua. Biomass in tanks $\left(\mathrm{kg} \mathrm{m}^{-3}\right)$ at regular intervals during the experimental period. $\mathrm{n} . \mathrm{d} .=$ no data

\begin{tabular}{|lcc|}
\hline & Year class 2002 & Year class 2003 \\
\hline Sep & n.d. & 5.4 \\
Nov-Dec & 12.7 & 8.6 \\
Jan-Feb & 8.3 & 8.0 \\
Apr & 4.7 & 4.4 \\
Jun & 13.1 & 8.6 \\
\hline
\end{tabular}

these exchanges in species proportion enhanced by a single environmental factor, or by a combination of factors? Is it possible that T. cooperi is for some reason less fit than T. murmanica to compete and survive in the rearing environment?

Increased host density, which results in a sudden increase in parasite multiplication, may alter the interaction between species and competition for resources. It is conceivable that higher host density favours one Trichodina species over the other.

Salinity was variable throughout the rearing period, due to an inflow of geothermal freshwater to control the temperature during the coldest months. The drop in salinity seems to coincide fairly well with the increasing proportion of Trichodina murmanica, which gradually increased when salinity dropped, reaching almost total dominance when salinity was at minimum. In April, salinity rose again, and in June the proportion of $T$. cooperi had increased slightly, but only in y.cl. 2002. In the final examination, the salinity had not returned to the same level found at the beginning of the rearing period, when salinity was at its maximum. According to our results, these changes in species dominance start when salinity has only become slightly lower than normal. Therefore, salinity is not an unlikely influence.

Temperature cannot be ruled out as an influencing factor. The cod juveniles were brought to the rearing facilities in September, when the sea temperature was at its maximum. The first examination was performed shortly thereafter. Only Trichodina cooperi was detected at that time. No examinations of Trichodina species have been performed on cod juveniles from this area to determine possible seasonal variations in species dominance. Therefore, we can only conclude that, at this time of the year, T. cooperi seems to be the dominant species in this wild environment. It is possible that fluctuations in species proportions similar to those we observed in this study also occur in nature. It 
is thus only speculative that variations in temperature could affect the proportion of these species. During the first 3 to 4 mo of the rearing period, the temperature in the rearing tanks follows the temperature of the open sea, dropping by 3 to $5^{\circ} \mathrm{C}$.

It is possible that a stronger relationship would have been observed if variations in one or more of the environmental factors discussed had been greater. These alterations in species proportion could be caused by one or more of these factors or, possibly, by other factors not considered here. Statistical analysis of the relationship between environmental factors and the progress of infections was considered impractical, due to paucity of data points.

The experimental work presented here was partially intended to describe the trichodinid situation under routine rearing conditions. In order to establish the true effect of the above-described environmental factors on the relationship between Trichodina species and Atlantic cod, it is necessary to perform experiments in which each factor can be controlled singularly.

Acknowledgements. We acknowledge a grant awarded by the Icelandic AVS-fund.

\section{LITERATURE CITED}

Barker DE, Cone DK, Burt MDB (2002) Trichodina murmanica (Ciliophora) and Gyrodactylus pleuronecti (Monogenea) parasitizing hatchery-reared winter flounder, Pseudopleuronectes americanus (Walbaum): effects on host growth and assessment of parasite interaction. J Fish Dis 25:81-89

Bush AO, Lafferty KD, Lotz JM, Shostak AW (1997) Parasitology meets ecology on its own terms: Margolis et al. revisited. J Parasitol 83:575-583

Carson FL (1990) Histotechnology, a self-instructional text. ASCP Press, Chicago

Dobberstein RC, Palm HW (2000) Trichodinid ciliates (Peritrichia: Trichodinidae) from the Bay of Kiel, with description of Trichodina claviformis sp. n. Folia Parasitol 47:81-90

Dogiel VA (1948) Parasitic protozoa of fishes from Peter the Great Bay. Izvestiya Vsesoyuznogo Nauchno-Issledovatel'skogo

Editorial responsibility: Dieter Steinhagen,

Hannover, Germany
Instituta Ozernogo i Rechnogo Rybnogo Khozyaistva 27: 17-66 (in Russian)

Hemmingsen W, MacKenzie K (1993) A checklist of the protozoan and metazoan parasites reported from the Atlantic cod, Gadus morhua L. Bull Eur Assoc Fish Pathol 13:134-137

Karasev AB, Mitenev VK, Shulman BS (1996) Ecological peculiarities of the parasite fauna of cod and pollock in the vicinity of the Kislaya Inlet tidal power plant, western Murman (The Barents Sea). Sarsia 80:307-312

Khan RA (2004) Disease outbreaks and mass mortality in cultured Atlantic cod, Gadus morhua L., associated with Trichodina murmanica (Ciliophora). J Fish Dis 27:181-184

Klein BM (1958) The 'dry' silver method and its proper use. J Protozool 5:99-103

Lom J (1958) A contribution to the systematics and morphology of endoparasitic trichodinids from amphibians with a proposal of uniform species characteristics. J Protozool 5:251-263

Lom J, Laird M (1969) Parasitic protozoa from marine and euryhaline fish of Newfoundland and New Brunswick. I. Peritrichous ciliates. Can J Zool 47:1367-1380

Nilsen F (2002) Parasitter hos torsk-Hvilke problemer kan man möte $\mathrm{i}$ et fremtidig torskeoppdrett? In: Glette J, Meeren TVD, Olsen RE, Skilbrei O (eds) Havbruksrapport, Fisken og havet, Særnr. 3. Havforskningsinstituttet, Bergen, p 101-102

Polyanskiy YI (1955) Materials of fish parasitology of the northern seas of the USSR. Parasites of the fish of the Barents Sea. Tr Zool Inst Akad Nauk SSSR 19:5-170 (in Russian)

Poynton SL, Lom J (1989) Some ectoparasitic trichodinids from Atlantic cod, Gadus morhua L, with a description of Trichodina cooperi n. sp. Can J Zool 67:1793-1800

Shtein GA (1973) Parasitic ciliates (Peritricha, Urceolariidae) from some fishes of the Barents Sea. Parazitologiya 7: 489-495 (in Russian)

Shtein GA (1976) Parasitic ciliates (Peritricha, Urceolariidae) of fishes of the White Sea. Acta Protozool 15:447-468 (in Russian)

Van As JG, Basson L (1989) A further contribution to the taxonomy of the Trichodinidae (Ciliophora: Peritrichia) and a review of the taxonomic status of some fish ectoparasitic trichodinids. Syst Parasitol 14:157-179

Xu KD, Song WB, Warren A (1999) Trichodinid ectoparasites (Ciliophora: Peritrichida) from the gills of cultured marine fishes in China, with the description of Trichodinella lomi n. sp. Syst Parasitol 42:219-227

Zhukov EV (1964) Parasitofauna of fishes of Chukotka. III. Protozoa of marine and freshwater fishes. General conclusions. Parazitol Sb 22:224-253 (in Russian)

Submitted: October 26, 2005; Accepted: March 27, 2006

Proofs received from author(s): August 17, 2006 